\title{
Letter from the Editor
}

\section{The Need for Birth Stories on Perinatal Pain}

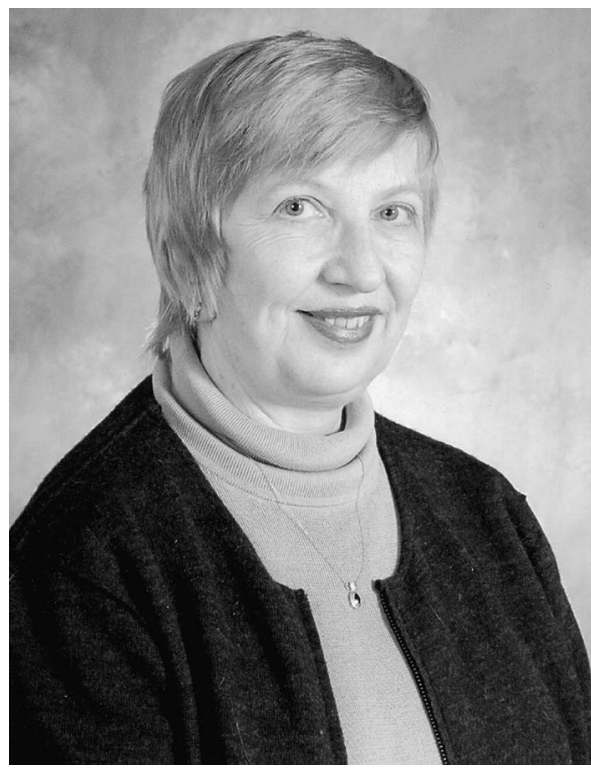

\begin{abstract}
Perinatal pain can be experienced by both mothers and infants. In this column, the author encourages readers to view an article by Gayle Page featured in this issue of the journal. Page's article shows the importance of protecting infants from unnecessary pain. The column author also points out that birth stories show the benefit of supporting women as they meet the challenges of a normal birth.

Journal of Perinatal Education, 13(3), 2-3; perinatal pain, newborn pain, birth stories, normal birth, childbirth education.

DOI: $10.1624 / 105812404 X 1699$
\end{abstract}

It seems that as a society we have it all backward when it comes to perinatal pain. Many newborns are thoughtlessly exposed to unnecessary pain, as if such experiences don't matter. Be sure to read, in this issue, the excellent article on newborn pain by Gayle Page, RN, DNSc, FAAN. After reading the article, help get the word out to parents and care providers about the importance of protecting newborns from avoidable pain lest it alter the infants' biological development.

Simultaneously, many women are encouraged to protect themselves from the rigors of childbirth with routine anesthesia and analgesia, as if no personal strength could be gained by coping with a normal level of childbirth pain. The strength to be gained has been documented in the birth stories of many women. An example is the following letter to the editor that I received from a nurse who independently discovered the joy of coping with normal birth, but then struggled with its contradiction to the beliefs underlying a medical model approach to viewing the challenge of birth:

\section{Letter to the Editor}

After having two children-anticipating pain, screaming my head off during labor-20 years ago I decided that, for my third child's birth, I would take control of my experience. I was determined to embrace the discomfort (pain) as it assisted me in getting from Point A to Point B. In essence, I decided the good that was to come from this experience would outweigh the bad. When I thought of the discomfort as something "good" instead of "bad," the whole birth experience changed for me.

It is hard for me to describe how to do this mental exercise, but it really changed my outlook on confronting pain and, ultimately, other challenges in life. I'll try to explain... 
First, I focused my thoughts on cells, organs, their activities, and processes. Then, I asked myself a number of questions. What does this experience mean to me and my body? What are the cells doing as I experience the various stages of labor and birth? How can I assist my body to do its work? If I take deep breaths, will that help at this moment? If I relax my arm to the point of jello, will that make it a little better? How do my cells need my support today? Which cells will I send to the site of injury or trauma? How should I line them up and direct them to move? What strategies would work best with today's challenge? Shall I send stronger cells? Do the cells that went to work yesterday-or even a moment ago-need a little break? What cells need permission to move forward? Perhaps I can say, "Okay, you cells that have worked so hard, take a break and let in the next set to do their work. Relax and go to the beach" (where would that be for cells?).

The process of addressing each question takes time and helps redirect thoughts. Depending on the duration of completing this mental dialogue, the birth experience (or any other important, challenging event we encounter) could be over! Wouldn't it be something if we discovered (through research, of course) that our minds can control each cell and direct it in certain tasks? What a discovery-and to think we could've been doing this all along!

In my own birth experience, I decided that pain was a good thing and that an important aspect of life's work was playing itself out during my discomfort. I accepted the discomfort until it subsided-and, to this day, I have a different, more positive approach to pain and other life challenges.

The questions and thoughts could go on and on. This is what I did on that day, some 20 years ago: I talked to each part of my body and entered into a relationship that called for closeness at the cellular level. I will never forget the experience. Until now, I have not told many people about this story-I feared other people's reactions to a nurse thinking of ordering her bodily functions rather than relying on medicine. However, in sharing my story, I truly and sincerely hope it helps others in some small way.

—Linda Clark Amankwaa, RN, PhD

\section{Spreading the Word about Normal Birth}

Clearly, the experience of pain by a newborn and the experience of normal labor pain by a birthing mother are very different events. The newborn is totally vulnerable, biologically and developmentally, and needs our protection lest the experience have long-term negative consequences. In contrast, the reader will note that Dr. Amankwaa begins by saying she decided she could take control of her birth experience. Since the 1970s, the research literature has been consistent in reporting that a woman's control or ability to participate in decisions during childbirth is associated with birth satisfaction and the perception of long-lasting, personal empowerment of a type that changes lives in positive directions.

How does the childbirth education community share this information to the birthing public and their health-care professionals? It's a difficult task. In its May 10, 2004, issue, Newsweek magazine published a feature on women's health and glorified giving women the choice to elect cesarean birth (p. 70). The same article exaggerated the risk of vaginal birth and minimized the risk of cesarean birth and, thus, did not promote fully informed birth choices. I was proud to see that the May 24, 2004, Newsweek issue included responses from Lamaze International's president, Barbara Hotelling, and Lamaze faculty member, Elaine Zwelling (p. 20). However, more people will likely read the original article rather than the letter-to-theeditor responses; thus, it is hard to promote normal birth when major media often does not.

Birth stories like the one published here, however, are invaluable. Please ask the women you teach or know to write similar brief stories and submit them to the Journal of Perinatal Education. I am more interested in descriptions of the impact of childbirth on a woman's life than a relating of labor details. We will periodically publish collections of these stories and make them copyright free for you to distribute digitally or in hard copy. Let's join the ongoing effort to share women's birth stories with others and, thereby, promote our mission of making normal birth the standard.

—Sharron S. Humenick, RN, PhD, LCCE, FAAN 